\title{
Forms of expression and recovery of vigor in mature trees of Lagerstroemia indica L.
}

Formas de expressão e recuperação do vigor em árvores adultas de Lagerstroemia indica L.

\author{
S. Ivasko Junior ${ }^{1 *} ;$ K. C. Lombardi ${ }^{2} ;$ R. Bobrowski ${ }^{3}$ \\ ${ }^{1}$ Departamento de Ciências Florestais, Laboratório de Paisagismo, Setor de Ciências Agrárias, Universidade Federal \\ do Paraná, 80210-170, Curitiba-Paraná, Brasil \\ ${ }^{2}$ Departamento de Engenharia Florestal, Laboratório de Solos e Nutrição Florestal, Setor de Ciências Agrárias e \\ Ambientais, Universidade Estadual do Centro-Oeste, 84500-000, Irati-Paraná, Brasil \\ ${ }^{3}$ Departamento de Engenharia Florestal, Laboratório de Silvicultura Urbana, Setor de Ciências Agrárias e \\ Ambientais, Universidade Estadual do Centro-Oeste, 84500-000, Irati-Paraná, Brasil \\ *severoivasko@gmail.com
}

(Recebido em 16 de agosto de 2019; aceito em 28 de outubro de 2019)

\begin{abstract}
The present study aimed to characterize different forms of vigor expression and its recovery in mature trees of Lagerstroemia indica L. planted in public spaces of Irati, Brazil. After measuring the vegetative vigor (shoot growth, internode length, leaf area and leaf color), physiological vigor (chlorophyll a and b content) and flowering vigor (inflorescence width and length) in the growing season of 2016, we applied lime and fertilizers in different treatments in the portion of soil under the dripline of each tree. These treatments consisted of an increase of $100 \%$ nitrogen, phosphorus and potassium contents measured in the soil, based on previous soil analysis. In order to evaluate the effect of fertilization, in the growing season of 2017 we remeasured the vigor of trees. We observed that treatments with potassium and phosphate fertilization provided the highest mean values for shoot growth, the mean distance of internodes, leaf area, inflorescence width and length. The variables dark green color index and content of chlorophyll $\mathrm{a}$ and $\mathrm{b}$ were not influenced by fertilizer treatments. Our findings show that fertilizers increased the expression of all variables related to vegetative vigor of $L$. indica in the urban environment, except for the dark green color index. This suggests .that nutrient availability is generally a limiting factor for the urban tree's growth. The shoot length can be used to characterize the vegetative vigor, and the inflorescence length in the evaluation of the flowering vigor. Keywords: Arboriculture, Tree Growth, urban tree.
\end{abstract}

O presente estudo teve por objetivo caracterizar as diferentes formas de expressão do vigor e a recuperação dele em árvores adultas de Lagerstroemia indica L. plantadas em áreas públicas de Irati, Brasil. Após mensurar o vigor vegetativo (comprimento do ramo, distância internós, área foliar e cor das folhas), o vigor fisiológico (conteúdos de clorofilas a e b) e o vigor de floração (comprimento e largura das inflorescências) na estação de crescimento de 2016, foi aplicado calcário e fertilizantes em diferentes tratamentos na porção do solo sobre a projeção de copa de cada árvore. Estes tratamentos consistiram na elevação, em 100\%, do conteúdo de nitrogênio, fósforo e potássio existentes no solo, de acordo com a análise prévia. Para avaliar os efeitos dos fertilizantes, na estação de crescimento de 2017 as árvores foram remedidas. Observou-se que os tratamentos com fertilização potássica e fosfatada promoveram as maiores médias para o crescimento dos ramos, para a distância internós, para a área foliar, para o comprimento e largura das inflorescências. As variáveis índice de cor verde escuro e conteúdo de clorofila a e b não foram influenciadas pelos tratamentos com fertilizantes. Constatou-se que os fertilizantes aumentaram a expressão de todas as variáveis relacionadas ao vigor vegetativo de $L$. indica no ambiente urbano, exceto para o índice de cor verde escuro. Isso sugere que a disponibilidade de nutrientes é geralmente um fator limitante para o crescimento das árvores urbanas. O comprimento do ramo pode ser utilizado para caracterizar o vigor vegetativo da espécie e o comprimento da inflorescência o vigor da floração.

Palavras-chave: Arboricultura, Árvores urbanas, Crescimento das árvores.

\section{INTRODUCTION}

In the face of the characteristics of the urban environment, the benefits provided by trees can be striking. Among other functions, they contribute to energy savings, reduction of atmospheric carbon dioxide, improvement of air quality, reduction of rainwater flow and aesthetic benefits [1]. 
However, cities can influence the adaptation of trees by high levels of air pollution, increased temperatures, low relative humidity and altered rainfall regime, which can be highly different if compared to the natural ecosystems where a species occurs [2].

Adverse environmental conditions, such as limited soil volume, can reduce the growth and vigor of trees by up to $50 \%$, which reduces the quality of ecosystem services provided along the life cycle of trees [3]. Thus, the local environment can change the quality and condition of trees, and this can be evaluated through variables that express the vigor of vegetative structures [4]. According to Tian et al. (2017) [5], the analysis of visible external conditions of trees may reflect the quality of their internal structure. Thus, trees that express low external quality can have internal conditions also compromised.

To know if trees have a good performance in urban environments, it's possible to measure their vigor using morphological characteristics related to leaves, branches, trunk, roots, flowers and canopy, and also by physiological characteristics related to their photosynthetic process $[6,7]$. Watson and Hewitt (2012) [3] used shoot length of the growing season and leaf size and color to correlate the root depth with vegetative vigor of urban trees in North Carolina, concluding that trees with deeper root system expressed greater vigor. Meanwhile, Petrova et al. (2014) [8] evaluated the physiological vigor of urban trees in Plovdiv, Bulgaria, by means of macronutrients, chlorophyll a, b and carotenoids present in leaves. Likewise et al. (1999) [6] quantified the vigor of trees in Basel, Switzerland, by means of their nutritional status related to a parasite damage on mature trees of Aesculus hippocastanum, Acer platanoides, Platanus x acerifolia, Tilia cordata and Tilia euchlora.

Results for the effects of fertilization on established and mature urban trees are scarce, but some works describe different problems [4, 9, 10, 11]. Brunetti and Fini (2017) [11] stated that fertilization of urban trees would be applied only to maintain the quality of trees by their adequate nutritional status in order to provide the expected benefits. Although, the fertilizer application after transplanting can be an unnecessary method to improve the plant establishment, growth, and physiology in urban areas [9], after three or more years this can be a valuable practice to maintain trees growth and quality [11]. Given the divergent information on how to perform fertilization and the specificities of urban soils, the amount of fertilizer to be applied must be known through local testing, taking into account soil conditions and nutritional requirements of the species. Even so, practical results of experiments related to fertilization of trees in the urban landscapes are very different, due to a series of variables that can influence its response, such as the characteristics of the soil and the species under study [10].

The species studied, Lagerstroemia indica, is native from the Middle East and is widely planted in the streetscape of cities in the south part of Brazil [12] because it is adapted to lower temperature ranges. Also, the small size, hardiness and the intensity and beauty of its flowering justify its great appeal in the urban environment [13]. Given the importance of this species, there is a need to deepen knowledge about the effect of fertilization, especially on mature trees, since the studies found are restricted to the development of seedlings of the species. In one of these studies, Cabrera and Devereaux (1999) [14] found that the application of higher dosages of nitrogen positively influenced post-transplant growth of $L$. indica, at concentrations between 15 and $60 \mathrm{mg} . \mathrm{L}^{-1}$ of the element.

In view of the above, this work aimed to characterize different forms of expression and vigor recovery in mature trees of $L$. indica, in addition to determining which formulation of compound fertilizer (NPK) can promote the best effect on vegetative, physiological and flowering vigor.

\section{MATERIAL AND METHODS}

\subsection{Description of the studied area}

The research was carried out with trees planted in two distinct parts of the urban forest, in the city of Irati, State of Paraná, Brazil (Figure 1). As we had a limited number of $L$. indica trees planted in groups, an urban park was chosen (Unit A), the only one in the city, and four sidewalk gardens (Units B, C, D and E). 


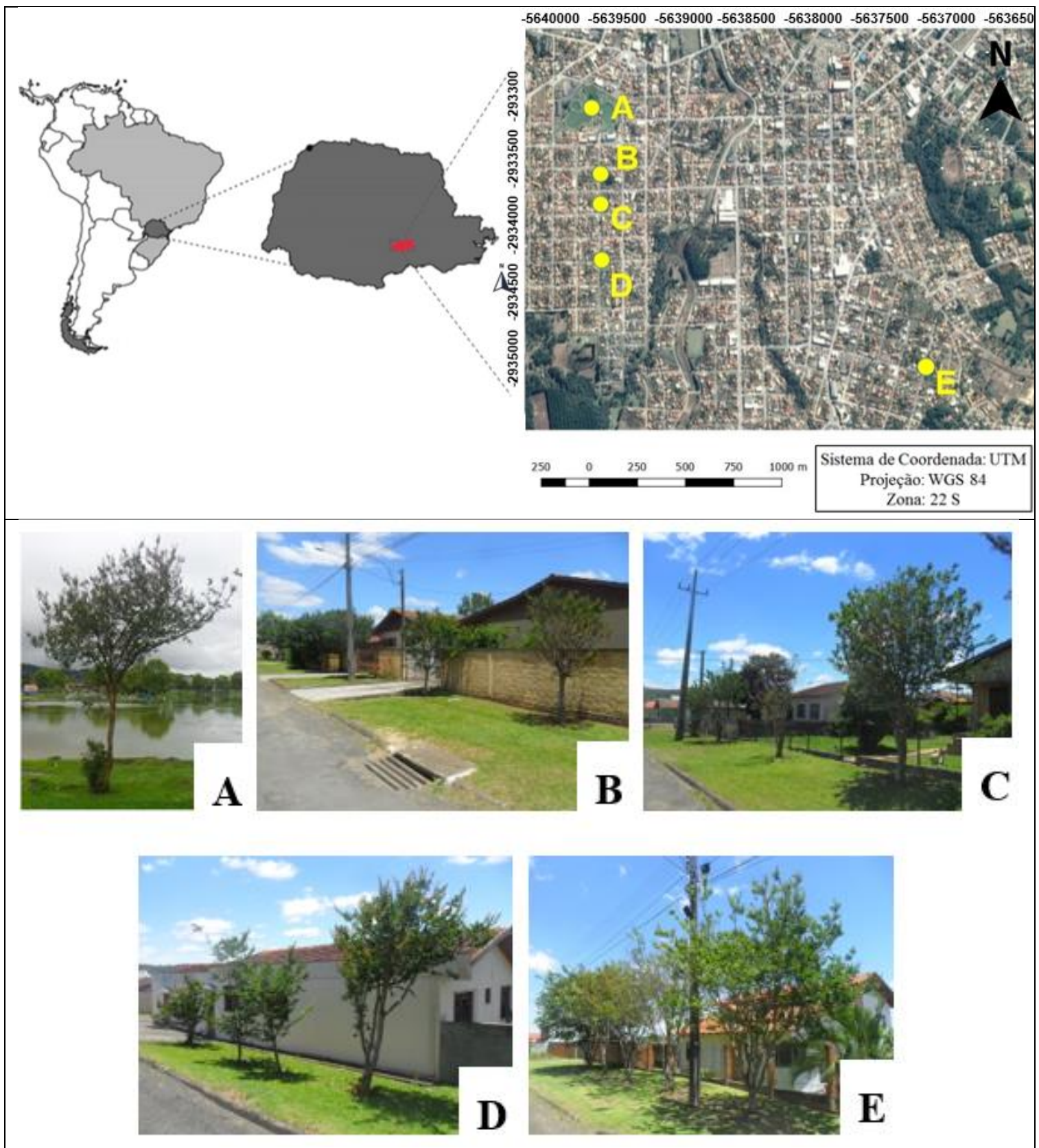

Figure 1: Map of location of sample units and general characteristics of them in the urban landscape of Irati, Paraná, Brazil. Fonte: The author.

The urban park (unit A) was created in 1988 where it used to be an ancient brick industry that operated until then, with a total area of $79,000.00 \mathrm{~m}^{2}$. The local landscape is composed by native trees like Anadenanthera colubrina and Syagrus romanzoffiana, and exotic species like Platanus $\mathrm{x}$ acerifolia, Salix babylonica, Acer negundo, Tipuana tipu, and Lagerstroemia indica [15]. The units $\mathrm{B}, \mathrm{C}, \mathrm{D}$ and $\mathrm{E}$, are sidewalk gardens, with average dimensions of $4.0 \mathrm{~m}$ wide and $15.0 \mathrm{~m}$ in length, and covered with Axonopus compressus grass and $L$. indica, which represents the highest proportion of trees in the streetscape of the city. 


\subsection{Methodological procedure}

In each unit, four soil samples were collected around each tree, at $0.20 \mathrm{~m}$ depth, equidistant in the middle of the crown dripline. These soil samples were homogenized into a single representative sample of each unit. The compound samples were analyzed in the Laboratory of Soil and Forest Nutrition, at Universidade Estadual do Centro-Oeste, following a standard methodology for soil analysis in Brazil, in order to get physical and chemical information.

From the soil analysis, we determined the need for liming (LN) and the amount of limestone to be applied (AL). According to technical recommendations for fertilization of ornamental plants in Brazil, the base saturation (V\%) of the soil was increased up to 60\% [16]. This was performed by the application of dolomitic limestone with fine granulometry 60 days before the application of NPK treatments (July of 2017), in order to get their maximum neutralization effect. This procedure was adapted for each unit, according to the soil analysis, and the amount of limestone was expressed in square meter of crown projection $\left(\mathrm{m}^{2} \mathrm{CP}\right)$ (Table 1$)$.

Table 1: Contents of the main elements quantified in the soil of each unit before the application of the treatments, with description of the average projection of crown area $(C A P)$, base saturation $(V)$, need for liming $(L N)$ and the amount of applied limestone (LA). " $X$ " indicates that there was no need for liming.

\begin{tabular}{|c|c|c|c|c|c|c|c|c|c|}
\hline \multirow{2}{*}{ Unit } & \multirow[t]{2}{*}{ pH } & $\mathbf{K}^{+}$ & $\mathbf{C a}^{2+}$ & $\mathrm{Mg}^{2+}$ & $\mathrm{H}^{+}+\mathrm{Al}^{3+}$ & \multirow{2}{*}{$\frac{\text { CAP }}{\mathbf{m}^{2}}$} & V & \multirow{2}{*}{$\begin{array}{c}\text { LN } \\
\text { g.m } \mathbf{m}^{-2} \mathbf{C P}\end{array}$} & \multirow{2}{*}{$\begin{array}{c}\text { LA } \\
\text { kg.tree }\end{array}$} \\
\hline & & \multicolumn{4}{|c|}{$\operatorname{cmol}_{\mathrm{c} . \mathrm{dm}} \mathrm{dm}^{-3}$} & & $\%$ & & \\
\hline A & 4.48 & 0.26 & 4.88 & 1.96 & 6.69 & 6.79 & 51.49 & 143.17 & 1.08 \\
\hline B & 5.37 & 0.67 & 6.84 & 2.59 & 4.15 & 7.94 & 70.88 & X & $\mathrm{X}$ \\
\hline $\mathrm{C}$ & 4.61 & 0.46 & 4.71 & 2.88 & 8.61 & 8.87 & 48.32 & 237.32 & 2.33 \\
\hline D & 4.46 & 0,42 & 4.91 & 3.82 & 7.64 & 7.07 & 54.50 & 112.86 & 0.88 \\
\hline $\mathrm{E}$ & 4.35 & 0.42 & 3.90 & 2.91 & 7.70 & 8.66 & 48.43 & 210.73 & 2.02 \\
\hline
\end{tabular}

The need for liming and the amount of limestone calculated according Silva and Lopes (2011) [17] were adapted to express values in grams per square meter of tree crown (LN) and kilograms per tree (LA) as follows:

$$
L N\left(g \cdot m^{-2} C P\right)=\frac{\left(V_{2}-V_{1}\right) \times C E C \times p}{100} \times 100
$$

Where:

LN: liming need in grams per square meter of crown area projection $\left(\mathrm{g} \cdot \mathrm{m}^{-2} \mathrm{CP}\right)$;

$\mathrm{V}_{2}$ : base saturation desirable in the soil;

$\mathrm{V}_{1}$ : base saturation determined in the soil;

CEC: cation exchange capacity;

$\mathrm{p}$ : correction factor for depth of liming application (for $0.20 \mathrm{~m}$ the value is 1.0).

$$
L A(k g . \text { tree })=\left(\mathrm{LN} \times \frac{\mathrm{CA}}{100} \times \frac{\mathrm{DL}}{20} \times \frac{100}{\mathrm{RTNP}}\right) \times \mathrm{CAP}
$$

Where:

LA: amount of limestone applied in kilograms per tree (kg.tree);

$\mathrm{LN}$ : liming need $\left(\mathrm{g} \cdot \mathrm{m}^{-2} \mathrm{CP}\right)$;

CA: liming coverage area $=100 \%$ of crown area projection;

DL: depth of liming application layer $(0.20 \mathrm{~m})$;

RTNP: relative total neutralizing power of the used lime (90\%);

CAP: mean crown area projection $\left(\mathrm{m}^{2}\right)$. 
NPK fertilization treatments were applied in the middle of the winter in 2017 (on July $15^{\text {th}}$ ) in order to solubilize the nutrients in the soil. With this procedure, we aimed to influence the growth and vigor of $L$. indica trees, which bloom in new branches of the next growing season in the spring [7].

The limestone and fertilizer formulations were applied by making 10 holes of $0.10 \mathrm{~m}$ deep in the soil, equidistantly spaced apart, and located under the last one third of the canopy radius of each tree. The total amount of fertilizer was divided by the number of holes per tree [7].

The simple fertilizers ammonium sulphate $(20 \% \mathrm{~N}$ and $24 \% \mathrm{~S})$, triple superphosphate $(46 \%$ $\left.\mathrm{P}_{2} \mathrm{O}_{5}\right)$ and potassium chloride $\left(60 \% \mathrm{~K}_{2} \mathrm{O}\right)$ were used for the composition of the fertilizers and their dosages because they are compatible with each other and do not produce undesirable effects in the mixture made [17].

\subsection{Treatments applied}

Treatments were planned considering the suggestions to interpret the soil test report [18] and the lack of recommendations to fertilize trees of $L$. indica at Brazilian soil conditions. Each tree received the application of one of the five treatments described below within its respective sample unit, resulting in five repetitions per treatment, each one located in a different sampling unit:

Treatment 1: control treatment, without addition of fertilizers;

Treatment 2: increase of phosphorus content from low to very high, according to the interpretation suggestions, corresponding to the application of $7 \mathrm{mg} \cdot \mathrm{dm}^{-3}$, on average, per tree;

Treatment 3: $100 \%$ increase of phosphorus content in relation to treatment 2, corresponding to the application of $12 \mathrm{mg} \cdot \mathrm{dm}^{-3}$, on average, per tree;

Treatment 4: $100 \%$ increase of nitrogen content in relation to treatment 1, corresponding to the application of $17 \mathrm{mg} . \mathrm{dm}^{-3}$, on average, per tree, keeping the values of phosphorus and potassium;

Treatment 5: 100\% increase of potassium content in relation to treatment 1, corresponding to the application of $25 \mathrm{mg} \cdot \mathrm{dm}^{-3}$, on average, per tree, keeping the values of nitrogen and phosphorus.

\subsection{Procedures to evaluate the characteristics of vigor}

\subsubsection{Vegetative vigor}

In each tree, we sampled five branches in the central portion of the crown, in each cardinal axis of crown projection. In each branch, the shoot length of the growing season, the distance of internodes, the average leaf area and the color of the leaves were measured to express different forms of growth and vigor in the species studied [7]. To determine the color and the leaf area, one leaf per sampled branch was collected, which corresponded to 20 leaves per tree. Leaves were scanned in an HP Deskjet F4180 printer in order to generate digital images of them. The average leaf area was measured using the Multispec ${ }^{\circledR}$, whereas the green intensity of the leaves was determined by ENVI ${ }^{\circledR}$ software. In this software, the HSB values of the images were quantified and the Dark Green Color Index (DGCI) was determined, through the following expression [20]:

$$
D G C I=\frac{\left(\frac{\mathrm{H}-60}{60}\right)+(1-\mathrm{S})+(1-\mathrm{B})}{3}
$$

Where:

$\mathrm{H}$ (hue): estimated in degrees, between $60^{\circ}$ (yellow) and $120^{\circ}$ (green)

$\mathrm{S}$ (saturation): estimated in decimal values

B (brigthness): estimated in decimal values. 


\subsubsection{Physiological vigor}

For this kind of vigor, we determined the chlorophyll $\mathrm{a}$ and $\mathrm{b}$ contents as these pigments cooperate in the process of light energy absorption during the process of photosynthesis [36]. To do this, three leaves from each tree were collected. In the same day, a sample of $7.85 \mathrm{~mm}^{2}$ size of each leaf was extracted. Each one was placed in a test-tube with $5 \mathrm{~mL}$ of the solvent dimethyl sulfoxide (DMSO) and were incubated in a water bath at $65^{\circ} \mathrm{C}$ for 150 minutes to extract the pigments. The absorbance of the chlorophylls was measured in a spectrophotometer Femto ${ }^{\circledR}$ model 600 , at wavelengths of $648 \mathrm{~nm}$ and $665 \mathrm{~nm}$ [21]. The chlorophyll content was estimated by means of the expressions:

$$
\begin{aligned}
& C a=14.85 \times(\mathrm{A} 665)-5.14 \times(\mathrm{A} 648) \\
& C b=25.48 \times(\mathrm{A} 648)-7.36 \times(\mathrm{A} 665)
\end{aligned}
$$

Where:

Ca: Chlorophyll a content in mg. $\mathrm{m}^{-2}$

$\mathrm{Cb}$ : Chlorophyll b content in mg. $\mathrm{m}^{-2}$

A665: Absorbance value at wavelength $665 \mathrm{~nm}$

A648: Absorbance value at wavelength $648 \mathrm{~nm}$.

\subsubsection{Flowering vigor}

We evaluated the flowering vigor by measuring the intensity of flowering. For this, the length and width of $10 \%$ of the total inflorescences counted in each tree, in each growing season, was randomly selected and measured.

\subsection{Data analysis}

In order to test the efficiency of the treatments applied to each tree, we evaluated the vegetative, physiological and flowering vigor before and after applying the fertilizers. The first evaluation was carried out in the 2016/2017 growing season (between November and January) and the second evaluation in the 2017/2018 growing season, in the same months. Data of the two evaluations were compared at 5\% probability level through the Welch paired test, which disregards the assumption of equality of variances [19]. Using a randomized block design, we tested the effect of the units A, $\mathrm{B}, \mathrm{C}, \mathrm{D}$ and $\mathrm{E}$ as blocks and the best treatment for each kind of vigor, with the application of the nonparametric Friedman test, since the data presented a non-normal distribution even after transformation. Tukey's test at 5\% probability of error was used to compare means. All statistical analyzes were performed in software R, version 3.4.2, by means of the agricolae package.

\section{RESULTS AND DISCUSSION}

\subsection{Vegetative vigor}

The Welch test showed that there was a significant difference in shoot length $(\mathrm{F}=165.41 ; \mathrm{p}$ value $\left.=7.21^{-35}\right)$, average distance of internodes $\left(\mathrm{F}=47.51 ; \mathrm{p}\right.$-value $\left.=9.71^{-12}\right)$, leaf area $(\mathrm{F}=13.90 ; \mathrm{p}$ value $\left.=2.53^{-4}\right)$ and dark green color $\left(\mathrm{F}=165.01 ; \mathrm{p}\right.$-value $\left.=4.26^{-26}\right)$. The expression of all these variables was superior in the growing season after fertilization (Figure $2 \mathrm{~A}$ ). 


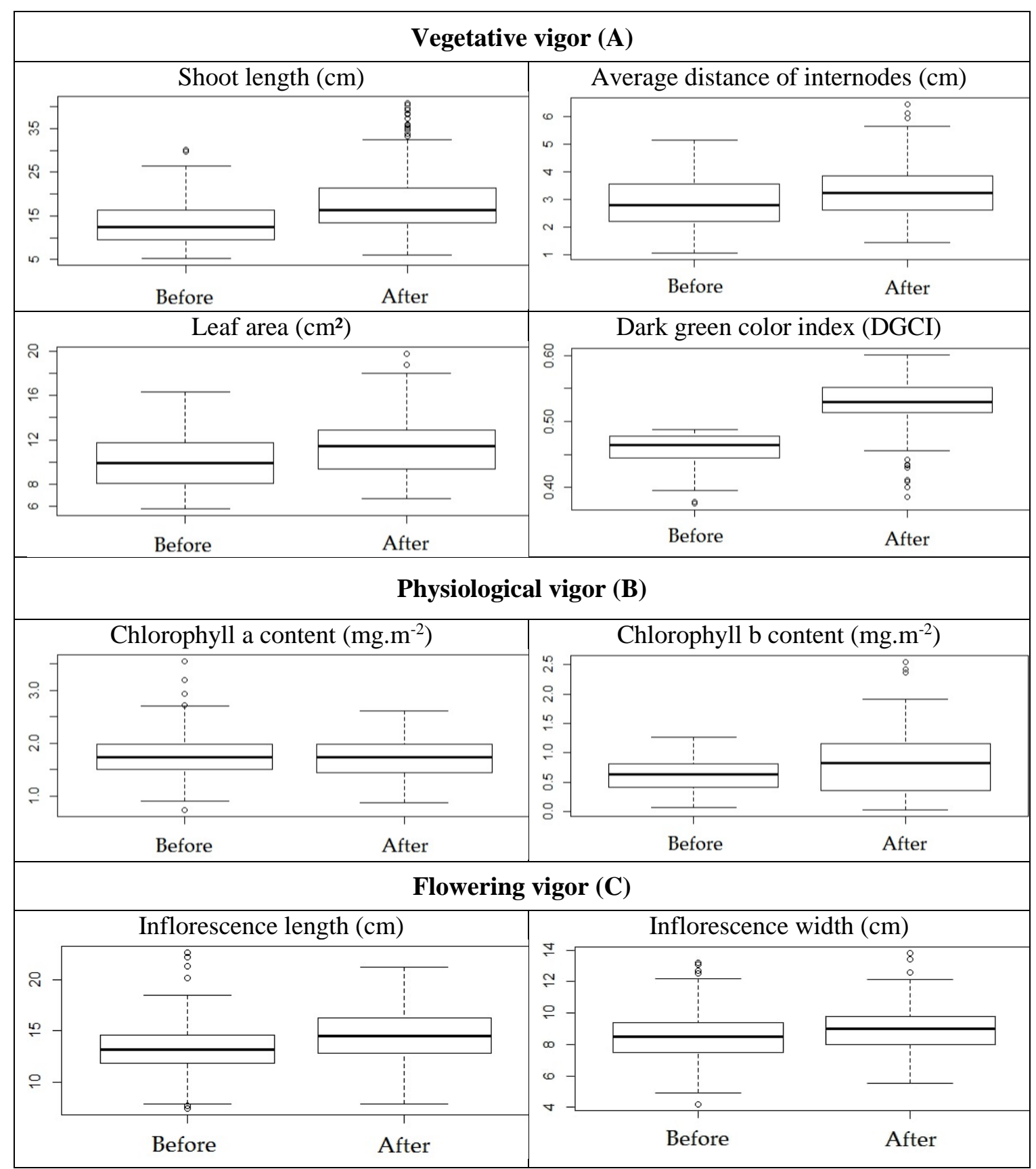

Figure 2: Range of data distribution for the variables of vegetative, physiological and flowering vigor measured before fertilization (2016) and after fertilization (2017) in Lagerstroemia indica trees.

Fertilization influenced the expression of all variables related to vegetative vigor of $L$. indica, in positively. This suggests that nutrient availability is generally a limiting factor for the growth of the urban trees [22], and thus, among management practices, fertilization is an essential practice to increase tree vigor [23]. The positive effect of fertilization can be explained by the periodic cleaning of foliage over the grass on sidewalks and in the public park. This practice contributes to the removal of litter (grass and leaf residues) that result in the loss of nutrients. Thus, additional fertilizer can influence the urban tree's development $[23,24]$ because nutritional deficiency of urban soils is considered as one of the main causes of tree vigor problems in cities [25].

When considering the units as blocks (A, B, C, D and E), there was no significant difference among them, however, treatments applied in these units showed a significant influence over three of the four variables related to vegetative vigor (Table 2A). 
Table 2: Average values of the vegetative (shoot length - SL, average internode distance - ID, leaf area$L A$, dark green color index-DGCI), physiological (Chlorophyll a and b content-CA $e$ CB) and flowering vigor (Inflorescence length and width - IL and IW) with their standard deviation values (SD), after application of treatments. Means followed by the same letter do not differ significantly from each other by the Tukey test $(p>0.05)$.

\begin{tabular}{|c|c|c|c|c|c|c|c|c|}
\hline \multicolumn{9}{|c|}{ Vegetative vigor (A) } \\
\hline Treatments & $\begin{array}{c}\text { SL } \\
(\mathrm{cm})\end{array}$ & SD & $\begin{array}{c}\text { ID } \\
(\mathbf{c m})\end{array}$ & SD & $\begin{array}{c}\mathbf{L A} \\
\left(\mathbf{c m}^{2}\right)\end{array}$ & SD & DGCI & SD \\
\hline $\mathrm{T} 1$ & $17.98 \mathrm{~b}$ & 6.32 & $3.25 \mathrm{ab}$ & 0.81 & $10.97 \mathrm{bc}$ & 2.49 & $0.52 \mathrm{a}$ & 0.04 \\
\hline $\mathrm{T} 2$ & $18.21 \mathrm{a}$ & 6.45 & $3.50 \mathrm{a}$ & 1.03 & $11.30 \mathrm{bc}$ & 2.67 & $0.53 \mathrm{a}$ & 0.03 \\
\hline $\mathrm{T} 3$ & $16.97 \mathrm{~b}$ & 5.36 & $3.14 \mathrm{~b}$ & 0.97 & $10.47 \mathrm{c}$ & 3.20 & $0.54 \mathrm{a}$ & 0.06 \\
\hline $\mathrm{T} 4$ & $17.92 \mathrm{~b}$ & 7.57 & $3.29 \mathrm{ab}$ & 0.91 & $11.72 \mathrm{ab}$ & 3.56 & $0.51 \mathrm{a}$ & 0.06 \\
\hline T5 & $18.56 \mathrm{a}$ & 7.57 & $3.54 \mathrm{a}$ & 0.81 & $12.03 \mathrm{a}$ & 1.91 & $0.54 \mathrm{a}$ & 0.02 \\
\hline \multirow[t]{2}{*}{ Mean } & 17.93 & 6.66 & 3.34 & 0.91 & 11.30 & 2.77 & 0.52 & 0.04 \\
\hline & \multicolumn{3}{|c|}{ Physiological vigor (B) } & \multicolumn{5}{|c|}{ Flowering vigor $(\mathrm{C})$} \\
\hline Treatments & $\begin{array}{c}\text { CA } \\
\left(\mathbf{m g} \cdot \mathbf{m}^{-2}\right)\end{array}$ & SD & $\begin{array}{c}\text { CB } \\
\left(\mathbf{m g} \cdot \mathbf{m}^{-2}\right)\end{array}$ & SD & $\begin{array}{c}\mathrm{IL} \\
(\mathrm{cm})\end{array}$ & SD & $\begin{array}{c}\text { IW } \\
(\mathbf{c m})\end{array}$ & SD \\
\hline $\mathrm{T} 1$ & $1.52 \mathrm{a}$ & 0.29 & $0.86 \mathrm{a}$ & 0.64 & $13.93 \mathrm{c}$ & 1.83 & $8.82 \mathrm{c}$ & 1.26 \\
\hline $\mathrm{T} 2$ & $1.84 \mathrm{a}$ & 0.27 & $0.57 \mathrm{a}$ & 0.47 & $15.10 \mathrm{~b}$ & 2.07 & $9.25 \mathrm{~b}$ & 1.29 \\
\hline $\mathrm{T} 3$ & $1.77 \mathrm{a}$ & 0.33 & $0.97 \mathrm{a}$ & 0.59 & $13.06 \mathrm{c}$ & 2.81 & $7.93 \mathrm{~d}$ & 1.16 \\
\hline $\mathrm{T} 4$ & $1.85 \mathrm{a}$ & 0.39 & $0.63 \mathrm{a}$ & 0.45 & $13.00 \mathrm{c}$ & 2.43 & $8.47 \mathrm{~cd}$ & 1.31 \\
\hline $\mathrm{T} 5$ & $1.78 \mathrm{a}$ & 0.51 & $0.74 \mathrm{a}$ & 0.40 & $16.25 \mathrm{a}$ & 1.98 & $9.94 \mathrm{a}$ & 1.22 \\
\hline Mean & 1.75 & 0.36 & 0.75 & 0.51 & 14.27 & 2.23 & 8.88 & 1.25 \\
\hline
\end{tabular}

The mean values presented significant differences among treatments, only for shoot length $\left(\chi^{2}=\right.$ 16.83, $\mathrm{p}$-value $\left.=9.3^{-13}, 4 \mathrm{df}\right)$, average distance of the internodes $\left(\chi^{2}=2.17\right.$, $\mathrm{p}$-value $\left.=4.14^{-3}, 4 \mathrm{df}\right)$ and leaf area $\left(\chi^{2}=5.09, \mathrm{p}\right.$-value $\left.=1.10^{-3}, 4 \mathrm{df}\right)$. The mean values of the coefficients of variation ranged from 8.12 to $37.04 \%$ and can be considered satisfactory because it is an experiment carried out in natural conditions of mature tree growth without the control of environmental effects and management practices.

For shoot length and average distance of the internodes (Table 2A), treatments T2 (increase of phosphorus content from low to very high, according to the interpretation suggestions) and T5 (100\% increase of the potassium content in relation to the treatment 1) were the ones that induced the greatest vigor expression. These treatments corresponded to average levels of $12 \mathrm{mg} \cdot \mathrm{dm}^{-3}$ of $\mathrm{P}$ $351 \mathrm{mg} \cdot \mathrm{dm}^{-3}$ of $\mathrm{K}^{+}$in the soil. It was observed that for shoot length these two treatments differed significantly from the others, whereas for average distance of the internodes they differed only from the treatment T3 (100\% increase of phosphorus content in relation to treatment 2). This suggests that a satisfactory response to phosphate fertilization occurs up to a certain level for this species, due to the vigor reduction when applied an extra level of this element in the soil.

Regarding the leaf area, the treatment with potassic fertilization (T5) promoted more positive responses in relation to the others, although they did not differ from the treatment with nitrogen fertilization (T4) as shown in Table 2A. The fact that potassium and phosphate fertilization increased the expression of vegetative vigor of $L$. indica may suggest a nutritional deficiency for this species or an extra absortion of these elements due to the increase of their content and disponibility in the soil. However, in addition to the nutritional aspects, the vigor expression can be correlated with other factors of the urban environment, such as air pollution, general soil conditions and photoperiod, which can cause morphological and physiological changes in trees. 
The no significant and similar responses among studied units (A, B, C, D, and E) is a good result to remark the effects of fertilizer treatments. It is also interesting because these units presented similar characteristics in terms of composition and size, although the distance among each other is more than $100 \mathrm{~m}$, what is quite difficult to get a design pattern when one tries to study established trees on the streetscape.

It is important to highlight that the treatments with the greatest influence over shoot length were the same ones that promoted the expression of a greater average distance of internodes (Table 2). Then, we suggest that there is a direct proportional relationship among these variables, and both can be considered as good indicators of $L$. indica vigor.

The best positive responses of the foliar area to nitrogen and potassium fertilization suggests that the supply of these nutrients may influence the photosynthetic activity and the patterns of growth and development of the studied trees. Although, in the study of Laclau et al. (2009) [26] with Eucalyptus grandis, nitrogen fertilization did not modify the foliar area but potassic fertilization enhanced the area, lifespan, and biomass of trees. In mature trees of Acer sacharum, Gradowski and Thomas (2008) [35], observed that trees fertilized with nitrogen and phosphorus combined with dolomite had the greatest shoot extension. In newly planted trees in urban areas, Harris et al. (2008) [27] state that nitrogen fertilization does not affect their growth, and this was also reported by Kim et al. (2015) [22] in a study about the effects of different NPK fertilization over four forest species planted in a fire disturbed urban forest. As we can see, nutrient application in the activity of fertilizing urban trees can promote different responses in the growth of trees, depending on their level of development or their age. That is why we must consider local analysis in order to recommend the application of fertilizers.

Although the dark green color index is proved to be influenced by the increase of nitrogen absorption by plants $[20,33]$ no significant difference was observed between the control treatment (T1) and the treatment with an increase in the content of nitrogen in the soil (T4) as shown in Table 2. Also, the significant response to potassic fertilization suggests that higher levels, above 351 mg. $\mathrm{dm}^{-3}$ (Treatment 5), may increase the development of $L$. indica. However, to enhance the vegetative development in the field, the best dosage depends on the specific and controlled experiment with fertilizer composed with this element in different progressive dosages. On the other hand, considering phosphate fertilization above $12 \mathrm{mg} . \mathrm{dm}^{-3}$ (Treatment 2), trees of L. indica can have a limited development, as verified in treatment 3 , which corresponded to a content equal to $24 \mathrm{mg} \cdot \mathrm{dm}^{-3}$ in the soil.

In an experiment with mature trees of Quercus robur L. and fertilization with NPK (12-12-17), in an urban park in Florence, Italy, Ferrini et al. (2005) [9] observed that fertilized plants showed higher shoot growth, leaf area, chlorophyll content and foliar gas exchange, as well as improved soil physical characteristics, such as better structure and lower compaction. In the long term, the addition of nitrogen may support the phosphorus release in the soil, since this process induces the development of the solubilizing bacteria of inorganic phosphate in the soil [32]. In contrast, in a study about the effects of nitrogen fertilization, Tian et al. (2017) [5] observed that an excessive dosage of nitrogen could reduce the phosphorus absorption, due to the competition for the active sites in the rhizosphere. However, in order to promote the best effect with fertilization, especially in the case of established urban trees, they must be exposed to an adequate amount of water, aiming at the balance of photosynthetic and physiological processes [9]. Due to that, it is difficult to propose fertilization activities in urban areas. Besides the great heterogeneity of soils, it is important to consider the adequate quantity demanded by the species and the optimum balance among all the necessary elements to be applied. As stated by Bruneti and Fini (2017) [11], urban trees should be fertilized to maintain their vitality and nutrition quality and not to increase their growth and productivity like happens in an agricultural system.

\subsection{Physiological vigor}

Data collected showed that the content of chlorophyll a $(\mathrm{F}=0.26$; $\mathrm{p}$-value $=0.61)$ and $\mathrm{b}(\mathrm{F}=6.57$; $\mathrm{p}$-value $=0.35$ ) were not influenced by the fertilization treatments as they did not vary significantly (Figure 2B). Such non-responsive characteristic of the variables used to measure the physiological vigor may be related to the degree of species adaptability to the urban environment. Since, newly 
planted trees undergo a process of slow photosynthetic acclimatization, causing them to present changes in concentration and chlorophyll fluorescence, a consequence of the photosynthetic adaptation to the new environment. On the other hand, mature trees are already adapted to the environmental conditions of cities and tend to present stable physiological conditions.

When considering the units as blocks (A, B, C, D and E), there was no significant difference between them (Table 2B), neither among treatments, for both the chlorophyll a content $\left(\chi^{2}=0.46\right.$, $\mathrm{p}$-value $=0.7616,4 \mathrm{df})$ and chlorophyll $\mathrm{b}$ content $\left(\chi^{2}=0.55, \mathrm{p}\right.$-value $\left.=0.8110,4 \mathrm{df}\right)$. This may explain the homogeneity of chlorophyll content among treatments in the present study, since the evaluated trees are mature, with more than 20 years after planting and apparently well adapted to the local environment. Ferrini and Baietto (2006) [10] analyzed the influence of fertilization with NPK (15-9-15) on total chlorophyll content in Liquidambar stryraciflua, Styphnolobium japonicum and Fraxinus excelsior planted in different urban sites in Milan, Italy. As in the present study, they did not find significant differences among trees fertilized from the non-fertilized ones, three years after transplanting them. However, unlike the present study, Ferrini et al. (2005) [9] observed a positive effect of fertilization with NPK (12-12-17) in the leaf chlorophyll content of Quercus robur L., so that the fertilized trees were more photosynthetically active. Several papers point out that the increase of leaf chlorophyll content is closely related to the levels of applied nitrogen fertilization $[28,29]$.

\subsection{Flowering vigor}

According to the Welch test, data collected before and after fertilization were significantly different in relation to the inflorescence length $\left(\mathrm{F}=38.88\right.$; $\mathrm{p}$-value $\left.=8.57^{-10}\right)$ and width $(\mathrm{F}=17.75$; $\mathrm{p}$-value $=2.91^{-5}$ ), and showed higher values in the growing season after fertilization (Figure 2C). When considering the units as blocks (A, C, D, E and F), there was no significant difference among them, however, treatments presented significant differences (Table 2C) for the inflorescence length $\left(\chi^{2}=13.85\right.$, $\mathrm{p}$-value $\left.=3.1^{-10}, 4 \mathrm{df}\right)$ and width $\left(\chi^{2}=23.78, \mathrm{p}\right.$-value $\left.=1.1^{-16}, 4 \mathrm{df}\right)$. The treatment T5 provided the greatest expression of flowering vigor in $L$. indica, and is related to an increase of $100 \%$ of the potassium content in relation to treatment 1 . It corresponds to average levels of 351 mg. $\mathrm{dm}^{-3}$ of $\mathrm{K}^{+}$in the soil. Treatment $\mathrm{T} 2$ had the second best influence over flowering and corresponded to a phosphorus content equal to $12 \mathrm{mg} \cdot \mathrm{dm}^{-3}$ in the soil. These results were similar to those observed to shoot length in the analysis of vegetative vigor (Table 2A), in which the two treatments also presented the highest averages. Although, in that case, they did not present significant differences among themselves, as occurred for the flowering vigor. The application of higher dosages of phosphorus (T3) reduced the flowering responses, as occurred for the vegetative vigor (Table 2A). This may indicate the possible occurrence of phytotoxicity by the excess of this nutrient in the soil, although the species were responsive to a content of $12 \mathrm{mg} \cdot \mathrm{dm}^{-3}$ of this element in the soil (T2).

The results for flowering vigor guide us to two possible explanations about the best performance of trees after fertilization. These explanations do not exclude each other due to the limited experimental conditions of evaluation. Both potassium and phosphorus fertilization showed a positive influence on flowering vigor, and this may be a response for certain species. The potassic fertilization, especially in the form of chlorate, can contribute to the uniformity of flowering, allowing floral induction to occur more consistently and even out of season in Dimocarpus longan [30]. The response to phosphate fertilization is related to the demand for this nutrient during the flowering process. Martinez et al. (2003) [31] observed higher phosphorus concentrations in flowers of Prunus persica than on the leaves. According to the same authors, phosphorus is a mobile element in the phloem, important in the polinic tube growth and pollen grain maturation.

Among all parts of a tree, flowers are the most noticeable to the urban population, which indicates that the aesthetic aspects may play an important role in the evaluation of the quality of life. The response to this visual stimulus involves human psychology, in which individuals associate well-groomed and colorful landscapes with pride of themselves and the community, for being careful about the environment in which they live [32]. Trees flowering can also supply nutrients and floral resources such as pollen and nectar to the regional pollinators. This relationship between fauna and flora can influence the ecosystem stability, contributing to the city's 
environmental balance [34]. From this point of view, it is essential to study not only the effects of fertilization, but also other alternatives that aim to intensify the flowering development, so that the benefits provided by them, mainly aesthetic, can be enhanced.

\section{CONCLUSION}

Our findings suggest that fertilizers increased the expression of all variables related to vegetative vigor of $L$. indica in urban environment, except for the dark green color index. They also improved the flowering vigor.

The shoot length can be used to characterize the vegetative vigor expression and the length of the panicles in the evaluation of the flowering vigor. The physiological vigor of $L$. indica was not responsive to fertilizers, which indicates that it cannot be a good parameter to evaluate the general condition of this species.

The expression of vegetative and flowering vigor were more influenced by potassium and phosphate fertilization, whose formulations representing $351 \mathrm{mg} \cdot \mathrm{dm}^{-3}$ of potassium and $12 \mathrm{mg} . \mathrm{dm}^{-}$ ${ }^{3}$ of phosphorus in the soil were the most responsive. However, trees response depends on the availability of these nutrients in the soil.

\section{ACKNOWLEDGMENT}

We thank CAPES for the grant of scholarship to the first author, contributing to the research.

\section{REFERENCES}

1. Roy S, Byrne J, Pickering C. A systematic quantitative review of urban tree benefits, costs, and evaluation methods across cities in different climatic zones. Urban For Urban Gree. 2012;11(4):351-363, doi.org/10.1016/j.ufug.2012.06.006.

2. Nuruzzaman MD. Urban heat island: Causes, effects and mitigation measures - A review. Int J Envir Monit Anal. 2015;3(2):67-73, doi: 10.11648/j.ijema.20150302.15.

3. Watson GW, Hewitt AM. The relationship between structural root depth and vigor of urban trees. Arboric Urban For. 2012;38(1):13-17.

4. Biondi D, Reissmann CB. Avaliação do vigor das árvores urbanas através de parâmetros quantitativos. Sci Forest. 1997;52:17-29.

5. Tian D, Li P, Fang W, Xu J, Luo Y, Yan Z, Zhu B, Wang J, Xu X, Fang J. Growth responses of trees and understory plants to nitrogen fertilization in a subtropical forest in China. Biogeosci. 2017;14(14):34613469, doi.org/10.5194/bg-14-3461-2017.

6. Flückiger W, Braun S. Stress factors of urban trees and their relevance for vigour and predisposition for parasite attacks. Acta Hortic. 1999;496:325-334, doi: 10.17660/ActaHortic.1999.496.40.

7. Harris RW, Clark JR, Matheny NP. Arboriculture: integrated management of landscape trees, shrubs, and vines. New Jersey: Prentice-Hall; 1999. 687 p.

8. Petrova ST, Yurukova LD, Velcheva ID. Assessment of the urban trees health status on the base of nutrient and pigment content in their leaves. J Biosc Biotechnol. 2014;3(1):69-77.

9. Ferrini F, Giuntoli A, Nicese FP, Pellegrini S, Vignozzi N. Effect of fertilization and backfill amendments on soil characteristics, growth, and leaf gas exchange of English oak (Quercus robur L.). J Arboric. 2005;31(4):182-190.

10. Ferrini F, Baietto M. Response to fertilization of different tree species in the urban environment. Arboric Urban For. 2006;32(3):93-99.

11. Brunetti C, Fini A. Fertilization in urban landscape. In: Ferrini F, Van Den Bosch CCK, Fini A. Routledge Handbook of Urban Forestry. New York: Taylor \& Francis Group; 2017. p. 434-448.

12. Backes P, Irgang B. Árvores cultivadas no sul do Brasil: guia de identificação e interesse paisagístico das principais espécies exóticas. Porto Alegre: Palotti; 2004. 204 p.

13. Lorenzi H, Souza HM, Torres MAV, Bacher LB. Árvores exóticas no Brasil: madeireiras, ornamentais e aromáticas, vol. 1. Nova Odessa: Plantarum; 2003. 352 p.

14. Cabrera RI; Devereaux DR. Crape Myrtle post-transplant growth as affected by nitrogen nutrition during nursery production. J Am Soc Hortic Sci. 1999;124(1):94-98, doi:10.21273/JASHS.124.1.94.

15. Schallenberger LS, Araujo AJ, Araujo MN, Deiner LJ, Machado GO. Avaliação da condição de árvores urbanas nos principais parques e praças do município de Irati-PR. Rev Soc Bras Arboriz Urbana. 2010;5(2):105-123, doi: http://dx.doi.org/10.5380/revsbau.v5i2. 
16. Oleynik J, Bragagnolo N, Bublitz U, Silva JCC. Análises do solo: tabelas para transformação de resultados analíticos e interpretação de resultados. $3^{\mathrm{a}}$ ed. Curitiba: EMATER; 2004. 64 p.

17. Silva DRG, Lopes AS. Princípios básicos para formulação e mistura de fertilizantes. Boletim técnico n.89. Lavras: editora UFLA; 2011. 46 p.

18. Moreira A, Motta ACV, Costa A, Muniz AS, Cassol LC, Zanão Júnior LA, Batista MA, Müller MML, Hager N, Pauletti V. Manual de adubação e calagem para o Estado do Paraná. Curitiba: Sociedade Brasileira de Ciência do Solo; 2017. 482 p.

19. Derrick B, Toher D, White P. Why Welch's test is Type I error robust. Quant Meth Psych. 2016;12(1):3038, doi: 10.20982/tqmp.12.1.p030.

20. Rocha JHT, Backes C, Borelli K, Prieto MR, Santos AJM; Godinho TO. Concentração de nutrientes e intensidade de cor verde em miniestacas de eucalipto. Biosc J. 2013;29(6):1848-1856.

21. Barnes JD, Balaguer L, Manrique E, Elvira S, Davison AW. A reappraisal of the use of DMSO for the extraction and determination of chlorophylls $\mathrm{a}$ and $\mathrm{b}$ in lichens and higher plants. Environ Exp Bot. 1992;32(2):85-100, doi: 10.1016/0098-8472(92)90034-Y.

22. Kim C, Jeong J, Park JH, Ma HS. Growth and nutrient status of foliage as affected by tree species and fertilization in a fire-disturbed urban forest. Forests. 2015;6(6):2199-2213, doi: 10.3390/f6062199.

23. Enloe HA, Lockaby BG, Zipperer WC, Somers G. Urbanization effects on leaf litter decomposition, foliar nutrient dynamics and aboveground net primary productivity in the subtropics. Urban Ecosyst. 2015;18(4):1285-1303, doi: 10.1007/s11252-015-0444-x.

24. Sun Y, Zhao S. Leaf litter decomposition in urban forests: test of the home-field advantage hypothesis. Ann Forest Sci. 2016;73(4):1063-1072, doi: 10.1007/s13595-016-0577-y.

25. Jonard M, André F, Giot P, Weissen F, Van Der Perre R, Ponette Q. Thirteen-year monitoring of liming and PK fertilization effects on tree vitality in Norway spruce and European beech stands. Eur J Forest Res. 2010;129(6):1203-1211, doi: 10.1007/s10342-010-0410-3.

26. Laclau JP, Almeida JCR, Gonçalves JLM, Saint-André L, Ventura M, Ranger J, Moreira RM, Nouvellon Y. Influence of nitrogen and potassium fertilization on leaf lifespan and allocation of above-ground growth in Eucalyptus plantations. Tree Physiol. 2009;29(1):111-124, doi: 10.1093/treephys/tpn010.

27. Harris JR, Day SD, Kane B. Nitrogen fertilization during planting and establishment of the urban forest: a collection of five studies. Urban For Urban Gree. 2008;7(3):195-206, doi: 10.1016/j.ufug.2008.03.001.

28. Hokmalipour S, Darbandi MH. Effects of nitrogen fertilizer on chlorophyll content and other leaf indicate in three cultivars of maize (Zea mays L.). World Appl Sci J. 2011;15(12):1780-1785.

29. Kuo YJ. Effects of fertilizer type on chlorophyll content and plant biomass in common Bermuda grass. Afr J Agric Res. 2015; 10(42):3997-4000, doi: 10.5897/AJAR2015.10226.

30. Matsumoto TK, Nagao MA, Mackey B. Off-season flower induction of longan with potassium chlorate, sodium chlorite, and sodium hypochlorite. Hort Technol 2007;17(3):296-300.

31. Martinez HEP, Souza RB, Bayona JA, Venegas VHA, Sanz M. Coffee-tree floral analysis as a mean of nutritional diagnosis. J Plant Nutrit. 2003;26(7):1467-1482, doi: 10.1081/PLN-120021055.

32. Zheng BX, Hao XL, Ding K, Zhou GW, Chen QL, Zhang JB, Zhu YG. Long-term nitrogen fertilization decreased the abundance of inorganic phosphate solubilizing bacteria in an alkaline soil. Scient Rep. 2017;7:1-10, doi: 10.1038/srep42284.

33. Lima CP, Backes C, Fernandes DM, Santos AJM, Godoy LG, Villas Boas RL. Uso de índices de reflectância das folhas para avaliar o nível de nitrogênio em grama-bermuda. Ci Rural. 2012;42(9):1-7, doi: 10.1590/S0103-84782012005000062.

34. Somme L, Moquet L, Quinet M, Vanderplanck M, Michez D, Lognay L, Jacquemart AL. Food in a row: urban trees offer valuable floral resources to pollinating insects. Urban ecosyst. 2016;19(3):1149-1161, doi: $10.1007 / \mathrm{s} 11252-016-0555-\mathrm{z}$.

35. Gradowski T, Thomas SC. Responses of Acer saccharum canopy trees and saplings to P, K and lime additions under high $\mathrm{N}$ deposition. Tree physiol. 2008;28(2),173-185, doi: 10.1093/treephys/28.2.173.

36. Taiz L, Zeiger E, Møller IM, Murphy A. Fisiologia e desenvolvimento vegetal. Porto Alegre: Artmed; 2017. $858 \mathrm{p}$. 